\title{
Effect of Summer Annual Forage and Type of Shade on Grazing Behavior of Beef Stocker Heifers
}

\author{
Guillermo Scaglia ${ }^{1}$ \\ ${ }^{1}$ Louisiana State University Agricultural Center, Jeanerette, LA, USA \\ Correspondence: Guillermo Scaglia, Louisiana State University Agricultural Center Iberia Research Station. P.O. \\ Box 466, Jeanerette, LA 70544-0466, USA. Tel: 1-337-276-5527. E-mail: gscaglia@agcenter.lsu.edu
}

Received: June 13, 2016

doi:10.5539/jas.v8n10p15

Accepted: August 3, $2016 \quad$ Online Published: September 15, 2016

URL: http://dx.doi.org/10.5539/jas.v8n10p15

The research is partially financed by NIFA. This work corresponds to a section of the approved State Project entitled "Utilization of forage resources by beef cattle in the Gulf Coastal Region of Louisiana".

\begin{abstract}
Heat stress in beef cattle is still one of the issues affecting animal performance in the beef cattle industry. Our objective was to evaluate the effect of two summer annual forages such as alyceclover (Alysicarpus vaginalis L.), and pearl millet (Pennisetum glaucum) with natural (trees) or artificial shade (80\% shade) on grazing behavior and on reducing the heat load of crossbred yearling heifers. On three consecutive years from mid-July to mid-September, 36 (Bos taurus $\times$ B. indicus) heifers (body weight $[\mathrm{BW}]=321 \pm 11.3 \mathrm{~kg}$ ) were randomly allotted $(\mathrm{n}=3)$ and continuously stocked in $12-1.33$ ha paddocks in a $2 \times 2$ factorial arrangement of treatments ( 2 forage types and 2 shade types) with three replicates. Heifers grazing on alyceclover gained more $(p=0.03)$ than those grazing pearl millet $(0.94$ and $0.80 \mathrm{~kg}$, respectively). Grazing behavior variables were not affected $(\mathrm{p}>0.05)$ by forage type and forage type $\mathrm{x}$ shade type interaction; however, shade type affected grazing and lying time $(\mathrm{p}<$ 0.05 ). Time of day (TOD) affected $(\mathrm{p}<0.05)$ grazing and standing time, number of steps taken, respiration rate, and panting scores. These negative effects are related with the greatest temperature humidity index between 1100 and $1459 \mathrm{~h}$. When data were analyzed by TOD, the negative effect on grazing behavior variables was not different for heifers with access to natural or artificial shades. Under the conditions of the present experiment, artificial shade provided protection for cattle. Grazing behavior parameters can be used to monitor heat load in grazing cattle.
\end{abstract}

Keywords: alyceclover, grazing behavior, heifers, pearl millet, THI

\section{Introduction}

Heat stress is a result of a negative balance between the net amount of energy flowing from the animal and the amount of heat energy produced and received by the animal, causing a greater accumulation of heat than cannot be dissipated (St. Pierre, Cobanov, \& Schnikey, 2003). Prolonged exposure to heat stress conditions in cattle reduces feed intake, growth, milk production, and reproductive efficiency (Hahn, 1985). Across the United States, heat stress results in estimated total annual economic losses of $\$ 370$ million in the beef industry. Beef cattle farms around the country are affected by heat waves (CDFA, 2006; Drovers Cattle Network, 2011) or normal weather conditions (high temperature and humidity like in the Gulf Coast region) that can severely affect animal performance and hence the profitability of the farm. Cattle with access to shade have consistently shown a reduction in core body temperature and respiration rate, although these positive effects are not always linked to improving performance (Mitloehner et al., 2001).

Respiration rate is the most reliable animal based indicator for heat stress because it increases with ambient temperature, lags solar radiation by approximately 1 hour, and is affected similarly in all heat stress categories (Brown-Brandl, Eigenberg, \& Nienaber, 2005). Another viable alternative in using body temperature to assess animal heat load would be to monitor the degree of panting or both panting and respiration (Gaughan, Holt, Hahn, \& Mader, 2000; Silanikove, 2000). Grazing behavior parameters may offer another tool to evaluate heat stress. Artificial shade is a viable alternative to provide appropriate protection for beef cattle under grazing 
conditions. Our objective was to evaluate the effect of shade type (natural or artificial) and pasture type on indicators of heat stress and grazing behavior of beef stocker heifers.

\section{Materials and Methods}

The present study was conducted at the Louisiana State University Agricultural Center (LSU AgCenter) Iberia Research Station (IRS) located in Jeanerette, LA (29 $57^{\prime} 54^{\prime \prime} \mathrm{W}$ latitude; $91^{\circ} 42^{\prime} 54^{\prime \prime} \mathrm{N}$ longitude; altitude $\left.5.5 \mathrm{~m}\right)$. The soil type is classified as Iberia silty clay loam poorly drained, very-fine, smectitic, hyperthermic, Typic Epiaquerts, with risk of flooding. The area was shaped ("turtle-back") to improve drainage. All procedures involving animals were approved by the LSU AgCenter Institutional Animal Care and Use Committee (A2011-17).

\subsection{Weather Data}

Monthly information on average temperatures $\left({ }^{\circ} \mathrm{C}\right)$ and rainfall $(\mathrm{mm})$ was obtained from a weather station located at the IRS approximately $540 \mathrm{~m}$ from the center of the experimental site used. Monthly average weather data for the last $30 \mathrm{yr}$ (1981-2010) were obtained from the National Weather Service Forecast Office (2016; select Jeanerette, LA).

Temperature humidity index (THI) was determined according to the Equation (1) outlined by Mader, Davis, and Brown-Brandl (2006):

$\mathrm{THI}=\{[0.8 \times$ ambient temperature $]+[(\%$ relative humidity $/ 100) \times($ ambient temperature -14.4$)]+46.4\}$

\subsection{Pasture Management, Treatments, and Analyses}

Alyceclover (Alysicarpus vaginalis L.; $12 \mathrm{~kg}$ per hectare) and pearl millet (Pennisetum glaucum; $22 \mathrm{~kg}$ per hectare) were used as a mean of increasing forage nutritive value (compared to bermudagrass) for young beef cattle as suggested by Scaglia \& Boland (2014). Every year on early May, Glyphosate ( $N$-(phosphonomethyl)glycine (Roundup ${ }^{\circledR}$; Monsanto Co., St. Louis, MO, USA) was applied for weed control; however, small areas (less than 0.01 hectare) with crabgrass (Digitaria sanguinalis) and johnsongrass (Sorghum halepense (L.) Pers.) were present within the grazed paddocks approximately 30 to 40 days into the grazing season. Alyceclover and pearl millet were planted using a $4.5 \mathrm{~m}$ no-till planter (1590 John Deere ${ }^{\circledR}$, Moline, IL, USA) with $25.4 \mathrm{~cm}$ between rows and at a planting depth of $1.9 \mathrm{~cm}$. All pastures were fertilized 45 days after planting with 60 units of nitrogen $(\mathrm{N})$ per hectare (130 kg per hectare urea; 46-0-0).

Forage mass was determined on day 0,30 , and 60 by clipping using a hand-held clipper (at $2 \mathrm{~cm}$ above the ground) inside fifteen- $0.25 \mathrm{~m}^{2}$ quadrats which were randomly placed along each of the paddocks. Samples of forages for nutritive value analyses were hand-plucked from every paddock on day 0,30 , and 60 , walking the pastures in a zig-zag pattern and a sample taken every 10 steps. Samples for nutritive value analysis were dried for dry matter (DM) determination in a forced-air oven at $55^{\circ} \mathrm{C}$ for 48 hours (AOAC, 2000). Forage samples were ground to pass a 1-mm screen using a Wiley mill (laboratory mill model 4; Arthur H. Thomas Co., Philadelphia, PA, USA). Forage samples were sent for wet chemistry analysis to a commercial laboratory (Dairy One Forage Laboratory, Ithaca, NY, USA). Crude protein was determined by analyzing N content of the samples according to the AOAC (2000) procedure (990.03). Determination of NDF following Van Soest, Robertson, and Lewis (1991) and ADF (AOAC, 2000; 973.18) were made with an automatic apparatus (Ankom 200/220 Fiber Analyzer; Ankom Technology, Macedon, NY, USA), following the procedure of the manufacturer recommended in the operator manual (Ankom Technology, 1997).

On day 0,30 , and 60 , vegetative cover was estimated in each paddock using transects. Five 10-m transects were randomly located within each treatment replicate. At $10-\mathrm{cm}$ intervals (100 points in each transect) along each transect, a sharpened point was lowered from above the vegetation and the first plant species intercepting the point was recorded (Heady, Gibbens, \& Powell, 1959).

Portable shades were built with $6.25 \mathrm{~cm}$ diameter pipe and welded into a $3 \mathrm{~m} \times 3.5 \mathrm{~m}$ frame. These structures provided $3.5 \mathrm{~m}^{2}$ of shade per animal which is more than the $2.3 \mathrm{~m}^{2}$ recommended for the class of cattle used in this experiment (Higgins, Agouridis, \& Wightman, 2011). The structure held a black woven polypropylene cloth (Gempler's; Janesville, WI, USA), which provides $80 \%$ shade. These shades were available in half $(\mathrm{n}=6$; three for each forage type) the paddocks while trees (water oaks; Quercus nigra) provide natural shade $\left(3.9 \mathrm{~m}^{2}\right.$ per heifer) to the other half ( $n=6$; three for each forage type) of the paddocks. Tree lines and artificial shades had an orientation east to west along one of the short sides of the rectangular-shaped paddocks. Mineral feeders were placed in the middle of all paddocks and the water troughs on the opposite side of the shade. Ambient temperature was determined in three paddocks per shade type (artificial shades and trees) randomly selected using common outdoor digital thermometers (AcuRite 00782A2; Chaney Instrument Co., Lake Geneva, WI, 
USA) placed approximately $2 \mathrm{~m}$ from the ground. Temperature was recorded once a week (Wednesdays) at 0900 , 1300 , and $1700 \mathrm{~h}$.

\subsection{Cattle Management and Variables Determined}

In three consecutive years, 36 crossbred (at least 5/8 Bos taurus and 3/8 or less B. indicus influence) heifers (15 to 16 months of age; body weight $[\mathrm{BW}]=321 \pm 11.3 \mathrm{~kg})$ were randomly allotted $(\mathrm{n}=3)$ to 12 paddocks $(1.33$ ha; 2.3 heifers per hectare; $724 \mathrm{~kg} \mathrm{BW}$ per hectare) in a 2 × 2 factorial arrangement with three replicates each in a continuous low stocking rate for a 60-day grazing period (mid-July to mid-September of each year). Previous experience with summer annual forages indicated a high risk of poor stands due to variable rainfall at the early stages of plant growth. This issue factored in the decision of using low stocking rates since the main objective of the study was to determine the effect of shade type on the response of these animals to environmental distress and its influence on grazing behavior. Regardless, information on pastures and animal performance are presented to better describe the production system during the experimental period. On two consecutive days (to reduce the effect of filling), heifers were weighed and body condition score (BCS) determined, values averaged (day -1 and 0 , day 30 and 31, day 59 and 60) and presented as those on day 0,30 , and 60 . On day 0 of the experimental period, heifers were dewormed with $1 \% \mathrm{w} / \mathrm{v}$ ivermectin (Ivomec Plus Injectable; Merial, Duluth, GA, USA). Fresh water and mineral mix that guaranteed $12 \% \mathrm{Ca}, 6 \% \mathrm{P}, 10 \% \mathrm{NaCl}, 2.50 \% \mathrm{Mg}, 0.75 \% \mathrm{~K}, 0.0043 \% \mathrm{Cu}$, $0.00012 \%$ Se, $0.0067 \%$ Zn, 200,000 IU of Vitamin A (Lone Star 126; Lone Star Feeds, Corpus Christi, TX, USA) were provided ad libitum.

\subsection{Grazing Behavior}

Every year, grazing behavior recordings were conducted through the entire grazing season on one heifer per treatment replicate, each wearing an animal activity monitor. This monitor (IceTag ${ }^{\mathrm{TM}}$, version 2.004 , IceRobotics, Midlothian, Scotland, UK) was attached to a Velcro ${ }^{\circledR}$ strap on the left rear leg just above the metatarsophalangeal joint. These units measured animal activity 8 times per second with an internal accelerometer. Time spent standing, active, lying, and number of steps taken by each heifer were recorded. Data were downloaded from the on-board memory to a personal computer and analyzed by IceTagAnalyser ${ }^{\mathrm{TM}}$ software (version 2.009; IceRobotics). Raw activity monitor data were transformed using the procedure of Aharoni et al. (2009) to partition out the amount of time spent standing still, grazing, and walking without grazing. In brief, the data were first summarized into 5-minute intervals. If less than 10 steps were taken during that interval, the animal was considered to be standing still; if between 10 and 80 steps were taken, the animal was considered to be grazing; and if more than 80 steps were taken, the animal was considered to be walking without grazing. Information obtained from each animal activity monitor was summarized by day (24-hour periods) and time of the day (TOD): 0700-1059, 1100-1459, 1500-1859; 1900-2259; 2300-02.59, and 0300-6:59.

In year 3, behavior data recorders developed by the Institute of Grassland and Environmental Research and made by Ultra Sound Advice (London, UK) were used (Champion, Rutter, \& Penning, 1997; Rutter, Champion, \& Penning, 1997). The data from the devices were analyzed with Microsoft ${ }^{\circledR}$ Windows $^{\text {TM }}$ based software (GRAZE; Ultra Sound Advice, version 0.801). The devices consisted of a computerized data logger, halter-mounted jaw movement sensor, and a custom made halter. The data logger was attached to the halter on the left side of the neck of four randomly selected animals, one in each treatment. Dummy loggers were attached to each of the animals for a 10-day adaptation period. On day 17 (period 1) and day 43 (period 2), the recorders were placed on the animals starting at 0730 taking approximately 15 minutes on each heifer. Data were collected in 24 hour periods over a 5 day period. Every day, all the heifers in the treatment replicate were taken to the working facilities and the animal with the device passed through the chute, batteries of the data logger changed and the group was taken back to the pasture. Based on the GRAZE output, number of grazing and ruminating mastications were calculated.

Every year, for five consecutive days per period from 0700 to 1900 hours, respiration rate (RR) and panting score (PS) were determined on all the animals by three observers. Every hour, RR was determined by counting the number of flank movements over 10 seconds and then converting this count to breaths per minute (bpm). Panting score was measured (following the same criteria as RR) using the 8-point scale defined by Gaughan, Mader, \& Holt (2008) after a modification to the 0 to 4.5 scale (Mader, Davis, \& Brown-Brandl, 2006), where $\mathrm{PS}=0$ describes an animal under no heat load, and PS $=4.5$ describes a severely heat-stressed animal.

\subsection{Statistical Analyses}

The experiment design was a $2 \times 2$ factorial arrangement of treatments with three replicates. Forage type (alyceclover or pearl millet) and type of shade (natural vs. artificial) were the main factors. Data were analyzed with PROC GLM of SAS (SAS Inst., Inc., Cary, NC, USA). Forage mass and nutritive value data were analyzed 
for forage type, year, and their interaction. For botanical composition, absolute cover was calculated by dividing species intercepts by total intercepts (Oates, Undersander, Gratton, Bell, \& Jackson, 2011). The cover estimates were categorized into the different components: main species (alyceclover or pearl millet), bare soil, and weeds. Partial average daily gain (ADG) per period (period 1 from day 0 to 30 and period 2 from day 31 to 60), total ADG (day 0 to 60 ), and beef productivity per hectare were analyzed for main factors and their interaction. In all cases, paddock was the experimental unit. Daily ( 24 hours) data (time spent standing, active, lying, and number of steps) from behavior recordings, number of grazing and ruminating mastication, respiration arte, and panting score were analyzed following the experimental design described using day as the repeated measure. Pedometer data (grazing, standing, and lying time, and number of steps), RR and PS were also analyzed for the effect of TOD (0700-1059, 1100-1459, 1500-1859; 1900-2259; 2300-02.59; 0300-6:59). Least squares means are reported for all variables with means separated by Tukey's adjustment. A significance level of $\alpha \leq 0.05$ was set for all analyses.

\section{Results and Discussion}

\subsection{Weather Data}

On average, year 2 had the greatest rainfall followed by year 1, despite the small precipitation in August of that year (Figure 1). In addition, August in year 2 had an average temperature $5{ }^{\circ} \mathrm{C}$ greater than the average historic temperature for the month. These rainfall and temperatures in year 2 may have positively impacted forage production and hence animal gains. Temperatures for year 1 and 2 were above the 30 year historic average while temperatures on year 3 were average. Ambient temperature determined under the artificial shades and trees (data not shown) with common outdoor digital thermometers indicated that, on average, there was a difference of approximately $1.7^{\circ} \mathrm{C}$ more under the artificial shades at all times.

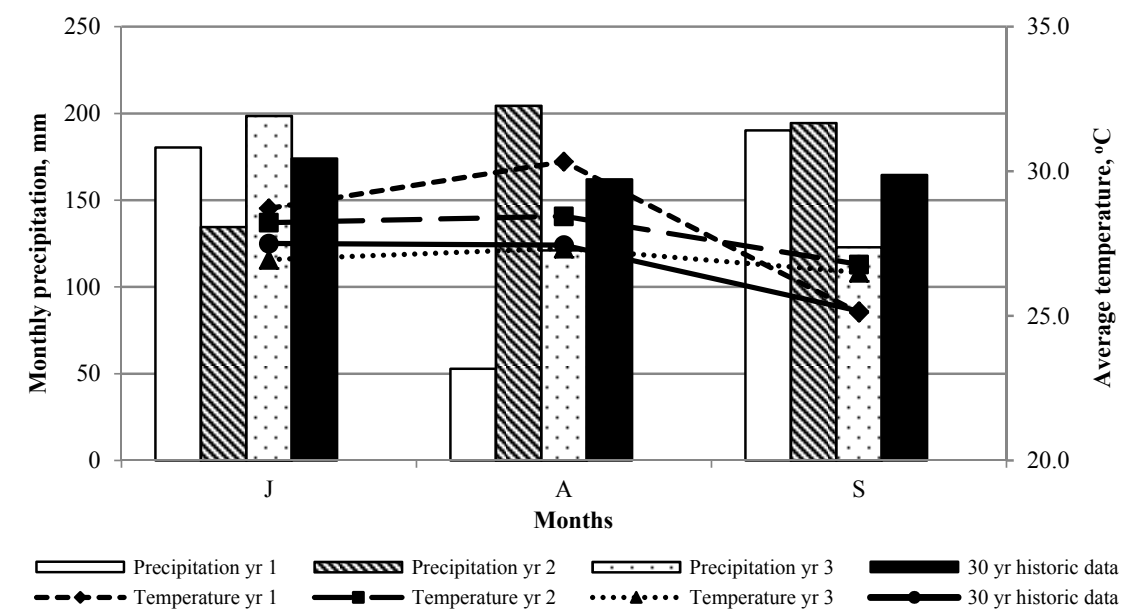

Figure 1. Monthly precipitation $(\mathrm{mm})$, average temperature $\left({ }^{\circ} \mathrm{C}\right)$, and $30 \mathrm{yr}$ historic averages at the experimental site

\subsection{Forage and Animal Production}

Figures 2 and 3 showed the 3-year average botanical composition of the experimental pastures. Pearl millet (Figure 2) presence in the pastures was greater than that of alyceclover (Figure 3). Due to the difference in plant architecture, stands of pearl millet were denser helping to shade potential weeds and/or covering soil that otherwise would be bare. 


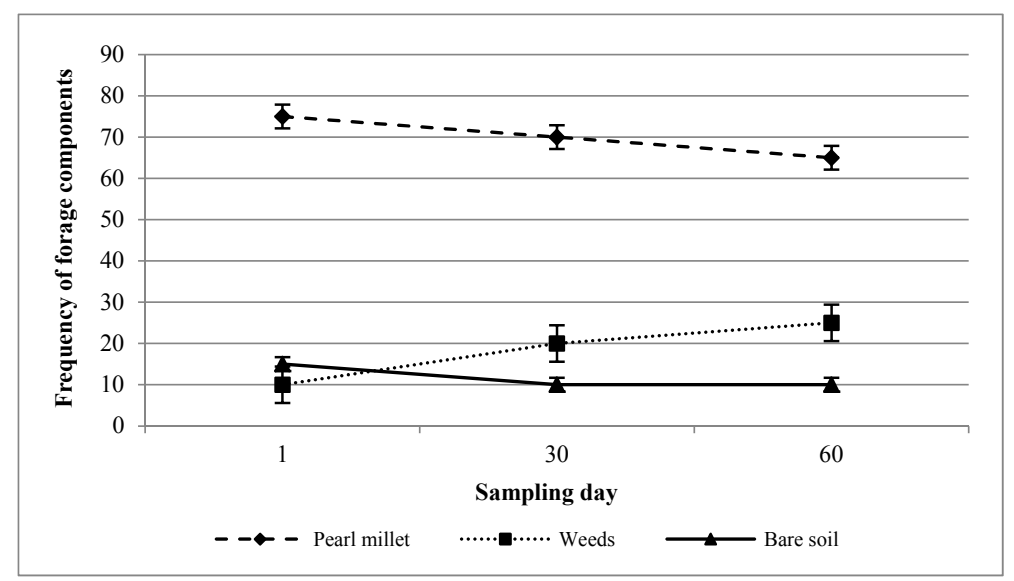

Figure 2. Frequency (\%) of forage components in pearl millet experimental pastures (average and SE of 3 years)

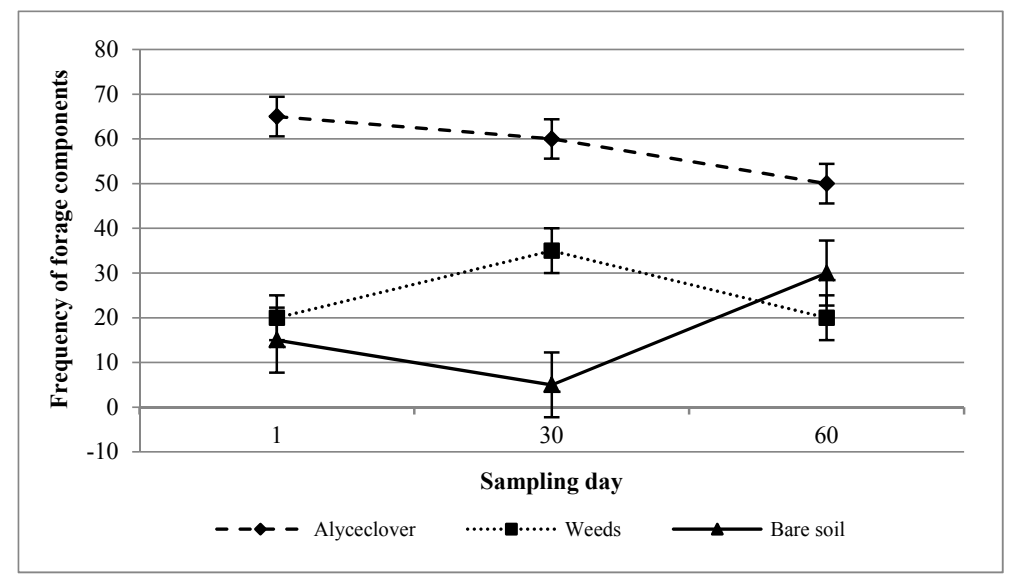

Figure 3. Frequency (\%) of forage components in alyceclover experimental pastures (average and SE of 3 years)

This impacted the frequency of each factor observed for each of the experimental pastures on day 30 and 60 (Figures 2 and 3). Weed frequency presence in alyceclover pastures varied from 20 to 39\% which is typical for this legume planted under no-tilled conditions (Bagley, Valencia, \& Sanders, 1985). Grazing started (day 0) when pearl millet was on average $51 \mathrm{~cm}$ tall $(3,990 \mathrm{~kg}$ DM per hectare) while alyceclover was $37 \mathrm{~cm}(2,522 \mathrm{~kg}$ DM per hectare). Forage mass in these pastures did not change $(\mathrm{p}=0.11)$ from day 0 to 30 , although a reduction $(\mathrm{p}=0.02)$ in alyceclover was observed on day $60(1,355 \mathrm{~kg}$ DM per hectare). A year effect was observed for forage mass production. Forage production in year $2(3,678 \mathrm{~kg}$ DM per hectare) was greater $(\mathrm{p}=0.03)$ than in the other two years $(2,342$ and 3,003 $\mathrm{kg}$ DM per hectare, for year 1 and 3 respectively). Greater rainfall and temperatures (above the historic average) may have contributed to this response. Forage production of summer annual grasses is closely related to weather conditions, mainly adequate rainfall during late spring and early summer (Teutsch, 2009). Nutritive value parameters were affected by forage type $(p<0.05)$ but not by year $(p>$ $0.05)$. As expected, nutritive value for alyceclover (a legume) was greater $(\mathrm{p}<0.05)$ than pearl millet (Table 1$)$; however, nutritive value parameters for the latter were adequate for yearling heifers as those used in the present experiment (NRC, 1996). Most forage systems in the Gulf Coast states are based on warm season perennial grasses, such as bermudagrass (Cynodon dactylon) and/or bahiagrass (Paspalum notatum), but these grasses do not meet the nutrient requirements of young growing animals (Scaglia \& Boland, 2014). There was no shade type or forage type $\mathrm{x}$ shade type interaction effect on ADG or beef produced per hectare (Table 2); hence, the main effect of forage type $(p=0.03)$ is discussed. Because of the difference between forage type's nutritive value, animal performance was greater $(\mathrm{p}=0.03)$ for heifers grazing alyceclover (Table 2 ) although no impact on BCS was observed ( $p>0.05$; data not shown). The weight gain difference for the experimental period (day 0 to 60 ) is explained by the ADG difference due to pasture type from d 31 to 60 ( 0.84 and $0.63 \mathrm{~kg}$ for alyceclover and pearl 
millet, respectively). Alyceclover maintained a greater nutritive value throughout the period despite its reduction in frequency (Figure 3) and hence in forage mass.

Table 1. Pasture type and year effect on nutritive value of the experimental pastures

\begin{tabular}{|c|c|c|c|c|c|c|c|}
\hline \multirow{2}{*}{ Item $^{2}$} & \multicolumn{3}{|c|}{ Pasture $^{1}$} & \multicolumn{4}{|c|}{ Year } \\
\hline & $\mathrm{AC}$ & PM & SEM & 1 & 2 & 3 & SEM \\
\hline $\mathrm{CP}$ & $21.0 \mathrm{a}$ & $12.9 b$ & 2.59 & 14.2 & 16.3 & 13.1 & 2.10 \\
\hline NDF & $43.5 b$ & $53.7 \mathrm{a}$ & 3.01 & 55.5 & 53.9 & 57.8 & 2.45 \\
\hline $\mathrm{ADF}$ & $36.6 \mathrm{~b}$ & $47.4 \mathrm{a}$ & 4.01 & 45.6 & 44.5 & 48.6 & 3.03 \\
\hline TDN & $61.9 \mathrm{a}$ & $57.1 \mathrm{~b}$ & 1.22 & 59.9 & 63.0 & 58.2 & 1.99 \\
\hline
\end{tabular}

Note ${ }^{1}$ Pasture: $\mathrm{AC}=$ Alyceclover; $\mathrm{PM}=$ Pearl millet; ${ }^{2} \mathrm{CP}=$ Crude protein, $\mathrm{NDF}=$ Neutral detergent fiber, $\mathrm{ADF}$ $=$ Acid detergent fiber, TDN $=$ Total digestible nutrients; ${ }^{\mathrm{a}, \mathrm{b}}$ Within a row means without a common superscript differ $(P<0.05)$.

Table 2. Average daily gain (ADG; kg) and beef produced per hectare (kg/ha).

\begin{tabular}{|c|c|c|c|c|c|c|c|}
\hline & \multicolumn{2}{|c|}{ Pasture $^{1}$} & \multicolumn{2}{|c|}{ Shade $^{2}$} & \multicolumn{3}{|c|}{$p$ value } \\
\hline & $\mathrm{AC}$ & PM & NS & AS & Pasture & Shade & Pasture $\times$ Shade \\
\hline ADG $(\mathrm{kg}), \mathrm{d} 0$ to 30 & 1.04 & 0.90 & 0.97 & 0.95 & 0.07 & 0.81 & 0.71 \\
\hline ADG $(\mathrm{kg}), \mathrm{d} 31$ to 60 & $0.84 \mathrm{a}$ & $0.63 b$ & 0.81 & 0.77 & 0.04 & 0.60 & 0.69 \\
\hline $\mathrm{ADG}(\mathrm{kg}), \mathrm{d} 0$ to 60 & $0.92 \mathrm{a}$ & $0.80 \mathrm{~b}$ & 0.91 & 0.83 & 0.03 & 0.18 & 0.84 \\
\hline Beef produced, $\mathrm{kg} / \mathrm{ha}$ & 128.9 & 111.1 & 123.5 & 112.3 & 0.10 & 0.32 & 0.88 \\
\hline
\end{tabular}

Note. ${ }^{1}$ Pasture: AC, Alyceclover; PM, Pearl Millet; ${ }^{2}$ Shade: NS, natural shade (trees); AS, artificial shade.

Daily gains were greater than those obtained by Bagley et al. (1985), who reported 0.77 and $0.61 \mathrm{~kg} / \mathrm{day}$ for steers (initial $\mathrm{BW}=318 \mathrm{~kg}$ ) grazing alyceclover and pearl millet, respectively; however, initial stocking rates were greater ( 6 and 12 steers per hectare, for alyceclover and pearl millet, respectively) than in the present experiment (2.3 heifers per hectare). Bermudagrass, a summer perennial grass is commonly used in the Gulf Coast region during this time of the year. Heifers of similar age and weight (14-16 months of age and $311 \pm 13.8$ $\mathrm{kg}$ of BW) grazing bermudagrass (var. 'Jiggs') at a similar stocking rate (2.5 heifers per hectare) gained 0.65 $\mathrm{kg}$ /day (Scaglia, unpublished data) during the same time period. This is not a surprise since summer annual forages have greater nutritive value than summer perennial forages (Ball, Hoveland, \& Lacefield, 2007). Closely related with a low stocking rate $(3.4$ and $5.4 \mathrm{~kg} \mathrm{DM} / \mathrm{kg}$ BW of grazing pressure on day 0 ) used in the experiment is the low productivity per unit of land (129 and $111 \mathrm{~kg}$ per hectare, for alyceclover and pearl millet, respectively). Greater stocking rates on these same forages allowed for $330(1.3 \mathrm{~kg} \mathrm{DM} / \mathrm{kg} \mathrm{BW}$ on day 0$)$ and $526 \mathrm{~kg}$ per hectare $(1.1 \mathrm{~kg} \mathrm{DM} / \mathrm{kg} \mathrm{BW}$ on day 0$)$ of beef produced, for alyceclover and pearl millet, respectively (Bagley et al., 1985).

\subsection{Temperature Humidity Index Effect on Grazing Behavior, Respiration Rate, and Panting Score}

There was no forage type or forage type $x$ shade type interaction $(p>0.05)$ on any of the variables determined; however, shade type had an effect on time of grazing $(p=0.03)$, standing $(p=0.04)$ and lying $(p=0.04$; Table 3) Several of the studies dealing with heat stress have been conducted under feedlot conditions (Mitloehner et al., 2001; Mader et al., 2006; Mader, Dahlquist, Hahn, \& Gaughan, 1999). Even though this segment of the beef cattle industry is economically very important, there are classes of beef cattle (most females and bulls) that spend most of their lifetime under grazing conditions. These conditions require the animal to walk more (hence spending more energy) for feed, water, and shade than under a feedlot setting; thus, grazing behavior as a measurement of cattle response to heat stress can be another viable option to use by producers because data are relatively easy to acquire. 
Table 3. Effect of forage and shade type on grazing behavior variables and heat stress indicators

\begin{tabular}{|c|c|c|c|c|c|c|c|}
\hline \multirow{2}{*}{ Item } & \multicolumn{2}{|c|}{ Forage $^{1}$} & \multicolumn{2}{|c|}{ Shade $^{2}$} & \multicolumn{3}{|c|}{$\mathrm{p}$ values } \\
\hline & $\mathrm{AC}$ & PM & NS & AS & Forage & Shade & Forage $\times$ Shade \\
\hline Grazing, min & 547 & 570 & $555 \mathrm{a}$ & $495 b$ & 0.21 & 0.03 & 0.06 \\
\hline Standing, min & 397 & 353 & $380 \mathrm{~b}$ & $470 \mathrm{a}$ & 0.11 & 0.04 & 0.08 \\
\hline Walking, min & 85 & 78 & 81 & 98 & 0.59 & 0.44 & 0.33 \\
\hline Number of steps & 1791 & 1858 & 1692 & 1747 & 0.41 & 0.09 & 0.09 \\
\hline Lying, min & 367 & 401 & $433 a$ & $385 b$ & 0.88 & 0.04 & 0.10 \\
\hline Grazing mastication per day & 5567 & 5933 & 4852 & 5013 & 0.75 & 0.05 & 0.52 \\
\hline Ruminating mastication per day & 29111 & 28423 & 36587 & 31282 & 0.63 & 0.07 & 0.88 \\
\hline Respiration rate ${ }^{3}$ & 102 & 95 & 109 & 99 & 0.55 & 0.66 & 0.54 \\
\hline Panting score ${ }^{4}$ & 0.9 & 0.8 & 0.9 & 0.7 & 0.77 & 0.89 & 0.69 \\
\hline
\end{tabular}

Note. ${ }^{1}$ Pasture: AC, Alyceclover; PM, Pearl Millet; ${ }^{2}$ Shade: NS, natural shade (trees); AS, artificial shade; ${ }^{3}$ Respiration rate in breaths per minute; ${ }^{4}$ Panting score following a scale where PS $=0$ describes an animal under no heat load, and PS $=4.5$ describes a severely heat-stressed animal.

Heat stress has long been known to adversely affect rumen health (Mishra, Martz, Stanley, Johnson, Campbell, \& Hilderbrand, 1970) due to a variety of biological and management reasons (Bernabucci, Bani, Ronchi, Lacetera, \& Nardone, 1999; Bernabucci, Lacetera, Baumgard, Rhoads, Ronchi, \& Nardone, 2009; Kadzere, Murphy, Silanikove, \& Maltz, 2002). Heat-stressed cows consume less feed and consequently ruminate less resulting in decreased buffering agents (ruminating is the primary stimulant of saliva production) entering the rumen (Bernabucci, Lacetera, Baumgard, Rhoads, Ronchi, \& Nardone, 2010). In the present study, since there was no effect of forage type or shade type on number of grazing or ruminating mastication (Table 3 ), the differences in grazing time (555 and 495 minutes for natural and artificial shade, respectively) may not have been related to dry matter intake (DMI). Heifers with artificial shade (under which the temperature was $1.7^{\circ} \mathrm{C}$ greater than under the trees) spent more time standing and less time lying down than those with access to natural shade (Table 3). This behavior is used as a mean of dissipating heat as indicated for steers grazing bermudagrass under similar conditions (Scaglia \& Boland, 2014).

Grazing behavior variables (except walking time), RR, and PS of grazing heifers were affected by TOD (Table 4). Heifers spent less time grazing $(p=0.04)$ and more time standing under the shade $(p=0.02)$, regardless of type of shade, between 1100 and $1500 \mathrm{~h}$ which is the peak of THI during the day (Figure 4). Lying time was greatest $(\mathrm{p}<0.05)$ from midnight to $0300 \mathrm{~h}$ but only different to the morning $(0700$ to $1100 \mathrm{~h})$ and the mid-afternoon $(1500$ to $1900 \mathrm{~h})$ hours. Respiration rate was greatest $(\mathrm{p}<0.05)$ from 1100 to $1459 \mathrm{~h}$ and from 1500 to $1859 \mathrm{~h}$ compared to early morning hours $(0700$ to $1059 \mathrm{~h})$. Panting score was greatest $(\mathrm{p}=0.01)$ from 1100 to $1459 \mathrm{~h}$ compared to PS from 0700 to $1059 \mathrm{~h}$.

Table 4. Effect of time of day on grazing behavior variables and heat stress indicators

\begin{tabular}{llllllll}
\hline \multirow{2}{*}{ Item } & \multicolumn{7}{c}{ Time of day } \\
\cline { 2 - 8 } & $0700-1059$ & $1100-1459$ & $1500-1859$ & $1900-2259$ & $2300-0259$ & $0300-0659$ & SEM \\
\hline Grazing, min & $140 \mathrm{a}$ & $27 \mathrm{~b}$ & $127 \mathrm{a}$ & $133 \mathrm{a}$ & $31 \mathrm{~b}$ & $59 \mathrm{~b}$ & 27 \\
Standing, min & $46 \mathrm{~b}$ & $129 \mathrm{a}$ & $51 \mathrm{~b}$ & $30 \mathrm{~b}$ & $49 \mathrm{~b}$ & $77 \mathrm{ab}$ & 31 \\
Walking, min & 8 & 2 & 13 & 16 & 9 & 18 & 8 \\
Number of steps & $410 \mathrm{~b}$ & $89 \mathrm{~d}$ & $697 \mathrm{a}$ & $259 \mathrm{c}$ & $63 \mathrm{~d}$ & $299 \mathrm{bc}$ & 63 \\
Lying, min & $10 \mathrm{c}$ & $61 \mathrm{ab}$ & $31 \mathrm{bc}$ & $51 \mathrm{ab}$ & $121 \mathrm{a}$ & $79 \mathrm{ab}$ & 40 \\
Respiration rate $^{1}$ & $101 \mathrm{~b}$ & $113 \mathrm{a}$ & $108 \mathrm{a}$ & n.d. & n.d. & n.d. & 2.8 \\
Panting score $^{2}$ & $0.6 \mathrm{~b}$ & $1.4 \mathrm{a}$ & $0.8 \mathrm{ab}$ & n.d. & n.d. & n.d. & 0.3 \\
\hline
\end{tabular}

$\overline{\text { Note. }}{ }^{1}$ Respiration rate in breaths per minute (n.d. $=$ no data) $;{ }^{2}$ Panting score following a scale where PS $=0$ describes an animal under no heat load, and $\mathrm{PS}=4.5$ describes a severely heat-stressed animal; ${ }^{\text {ab, }, \mathrm{c}, \mathrm{d}}$ Within a row means without a common superscript differ $(P<0.05)$. 
In the 1960's, it was accepted that temperature and humidity affect animals' physiology which in turn affects how they behave including all the activities related to grazing behavior (Ehrenreich \& Bjugstad, 1966). Additionally, the trend that started decades ago of selecting higher producing cattle with great growth rate and metabolic activity increases body heat load, thus amplifying heat stress in cattle (West, 1994). Environments of high temperatures and humidity are detrimental to the productivity of commercial animal agriculture.

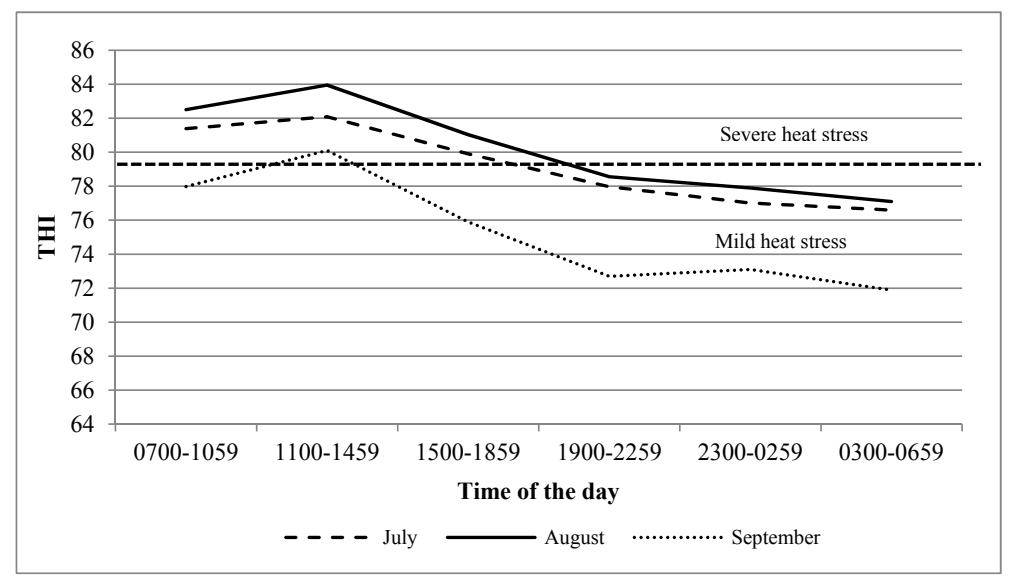

Figure 4. Average temperature humidity index (THI) at different time of the day during the experimental period

The Scientific Committee on Animal Health and Animal Welfare (SCAHAW, 2001) suggested that the threshold temperature where adverse effects on DMI, growth, and feed efficiency are readily apparent for beef cattle is $30^{\circ} \mathrm{C}$ with a relative humidity less than $80 \%$ and $27{ }^{\circ} \mathrm{C}$ with a relative humidity over $80 \%$ (Hahn, 1999). The 3 year-average THI that heifers were exposed throughout the grazing seasons is reported by TOD in Figure 4. Also included on it is the definition (dotted lines) of mild and severe heat load (THI of 72 and 79, respectively). Armstrong (1994) reported that B. taurus cattle (i.e., British and continental breeds) exhibited mild heat load when the THI is above 72 (lower dotted line in Figure 4). When THI is at or greater than 79, B. taurus cattle exhibited severe heat load (Hahn \& Mader, 1997). In the present experiment, heifers were crossbred with a genetic make-up of $3 / 4$ to $5 / 8$ B. taurus and $1 / 4$ to $3 / 8$ B. indicus. Bos indicus cattle (i.e., Brahman, Nellore, etc.) are well adapted to tropical conditions (high temperature, high humidity, external parasite resistance, etc.) which make them (and their crosses with $B$. taurus cattle) an excellent strategy to use them in the Gulf Coast region (Frisch \& Vercoe, 1984; Finch, 1984; Bennett, Finch, \& Holmes, 1985). Sprinkle et al. (2000), working with Angus, Brahman $\times$ Angus, and Tuli $\times$ Angus lactating and non-lactating cows, reported that in early summer the Tuli $\times$ Angus cows spent more time in the shade than the Brahman $\times$ Angus and less time during late summer. These results were probably due to the fact that in early summer only $19 \%$ of the hourly time periods had a THI less than 72 ; however, there were $59 \%$ of the hourly time periods that had a THI between 72 and 79 and $22 \%$ of the hourly periods with a THI exceeding 79. These authors concluded that Brahman crosses had a better adaptation to elevated temperatures than Tuli crosses (Sprinkle et al., 2000). Scaglia and Boland (2014), under similar weather conditions to those in the present experiment, observed that between $0600 \mathrm{~h}$ and midnight for all four months of grazing season (June to September) THI was above that considered to provoke mild heat stress on cattle. Even more dramatic to observe was the fact that the THI for June, July, and August between 0600 and $2100 \mathrm{~h}$ would cause a severe heat load (Scaglia \& Boland, 2014). Similar data were observed for the present experiment (Figure 4). Even though it was reported in feedlot conditions, during heat stress, eating behavior decreased ( 7.1 vs. $9.1 \%$ ), drinking behavior increased ( 3.1 vs. $1.7 \%$ ), standing behavior increased (48.1 vs. $42.0 \%)$, lying behavior decreased (41.1 vs. $44.3 \%)$, and agonistic behavior decreased (2.6 vs. $0.2 \%)$ for heat stressed cattle vs. those in a thermoneutral zone, respectively (Brown-Brandl et al., 2006). Scaglia and Boland (2014) reported that steers spent less time grazing, walking and lying and more time standing (to dissipate heat) during the period of peak THI as well as during the first 3 months of the grazing period. In the present experiment a similar impact (except for walking time) was observed due to THI.

Quantification of heat stress is complicated by acclimation of animals (Robinson, Ames, \& Milliken, 1986) and breed differences in their susceptibility to it (Hammond, Chase, Bowers, Olson, \& Randel, 1998; Gaugham, Mader, Holt, Josey, \& Rowan, 1999). In the present experiment, heifers were born and raised at the IRS and had 
a similar (1/4 to $3 / 8)$ B. indicus influence which make them an appropriate model for the study. Results from performance trials with shaded and unshaded feedlot cattle have shown inconsistent results (Mader et al., 2006). Lack of performance improvement from shaded treatments can be explained by the ability of cattle to acclimate and compensate for a short-term suppression in feed intake and growth resulting from a heat stress event (Hahn, 1982; Mader et al., 1999). During times of high solar radiation, high temperature, and high humidity, a reduction of solar radiation may be a method of reducing heat stress (J. K. Blackshaw \& A. W. Blackshaw, 1994; Valtorta, Leva, \& Gallardo, 1997; Paul, Turner, \& Larson, 1999), improving animal well-being and preventing death in extreme cases.

\section{Conclusions}

In the present study, artificial shades that provided $80 \%$ interference promoted an acceptable environment for grazing cattle. Despite the fact of not having a negative control (no shade), it was possible to determine the negative effect of greater THI (through TOD) on grazing behavior, RR, and PS of crossbred yearling heifers. It can be assumed that with no shade available these negative effects demonstrated under these experimental conditions would have been greater. Grazing behavior variables such as grazing and standing time can be used to evaluate the heat load of grazing cattle during summer. Further research to generate data that can allow a response curve on the effect of THI on grazing behavior is warranted.

\section{References}

Aharoni, Y., Henkin, Z., Ezra, A., Dolev, A., Shabtay, A., Orlov, A., ... Brosh, A. (2009). Grazing behavior and energy costs of activity: A comparison between two types of cattle. Journal of Animal Science, 87, 2719-2731. http://dx.doi.org/10.2527/jas.2008-1505

Ankom Technology. (1997). Methods for Determining Neutral Detergent Fiber. Ankom Technology Corp., Fairport, NY.

AOAC. (2000). Official Methods of Analysis (17th ed.). Assoc. Off. Anal. Chem. Gaithersburg, MD.

Bagley, C. P., Valencia, J. M., \& Sanders, D. E. (1985). Alyceclover: A summer legume for grazing. Louisiana Agriculture, 28, 16-17.

Ball, D. M., Hoveland, C. S., \& Lacefield, G. D. (2007). Southern forages (4th ed.). Int. Plant Nutr. Inst., Norcross, GA.

Bennett, I. L., Finch, V. A., \& Holmes, C. R. (1985). Time spent in shade and its relationship with physiological factors of thermoregulation in three breeds of cattle. Applied Animal Behaviour Science, 13, 227-236. http://dx.doi.org/10.1016/0168-1591(85)90046-2

Bernabucci, U., Bani, P., Ronchi, B., Lacetera, N., \& Nardone, A. (1999). Influence of short and long-term exposure to a hot environment on rumen passage rate and diet digestibility in Friesian heifers. Journal of Dairy Science, 82, 967-973. http://dx.doi.org/10.3168/jds.S0022-0302(99)75316-6

Bernabucci, U., Lacetera, N., Baumgard, L. H., Rhoads, R. P., Ronchi, B., \& Nardone, A. (2010). Metabolic and hormonal acclimation to heat stress in domesticated ruminants. Animal, 4, 1167-1183. http://dx.doi.org/ 10.1017/S175173111000090X

Bernabucci, U., Lacetera, N., Danieli, P. P., Bani, P., Nardone, A., \& Ronchi, B. (2009). Influence of different periods of exposure to hot environment on rumen function and diet digestibility in sheep. International Journal of Biometeorology, 53, 387-395. http://dx.doi.org/10.1007/s00484-009-0223-6

Blackshaw, J. K., \& Blackshaw, A. W. (1994). Heat stress in cattle and the effect of shade on production and behaviour: A review. Australian Journal of Experimental Agriculture, 34, 285-295. http://dx.doi.org/ 10.1071/EA9940285

Brown-Brandl, T. M., Eigenberg, R. A., \& Nienaber, J. A. (2005). Heat stress risk factors for feedlot heifers. Proceedings of the 5th International Livestock Environmental Symposium of the American Society of Agricultural Engineers (pp. 559-565). St. Joseph, MI.

California Department of Food and Agriculture. (2006). Hot topics affecting California Agriculture. Retrieved April 3, 2015, from http://www.cdfa.ca.gov/exec/Public_Affairs/pdf/AGOnAg080306.pdf

Champion, R. A., Rutter, S. M., \& Penning, P. D. (1997). An automatic system to monitor lying, standing and walking behaviour of grazing animals. Applied Animal Behaviour Science, 54, 291-305. http://dx.doi.org/10.1016/S0168-1591(96)01210-5 
Drovers Cattle Network. (2011). Retrieved April 4, 2015, from http://www.cattlenetwork.com/cattle-resources/ hot-topics/Heat-wave-killsas-many-as-4000-cattle-last-week-in-Iowa-126763608.html

Ehrenreicht, J. H., \& Bjugstad, A. J. (1966). Cattle grazing time is related to temperature and humidity. Journal of Range Management, 19, 141-142. http://dx.doi.org/10.2307/3895398

Finch, V. A. (1984). Heat as a stress factor in herbivores under tropical conditions. In F. M. C. Gilchrist \& R. I. Mackie (Eds.), Herbivore Nutrition in the Subtropics and Tropics (pp. 89-105). The Science Press Ltd., Craighall, South Africa.

Frisch, J. E., \& Vercoe, J. E. (1984). An analysis of different cattle genotypes reared in different environments. Journal of Agricultural Science, 103, 137-153. http://dx.doi.org/10.1017/S0021859600043409

Gaughan, J. B., Holt, S. M., Hahn, G. L., \& Mader, T. L. (2000). Respiration rate-Is it a good measure of heat stress in cattle? Asian-Australian Journal of Animal Science, 13, 329-332.

Gaughan, J. B., Mader, T. L., \& Holt, S. M. (2008). A new heat load index for feedlot cattle. Journal of Animal Science, 86, 226-234. http://dx.doi.org/10.2527/jas.2007-0305

Gaughan, J. B., Mader, T. L., Holt, S. M., Josey, M. J., \& Rowan, K. J. (1999). Heat tolerance of Boran and Tuli crossbred steers. Journal of Animal Science, 77, 2398-2405. http://dx.doi.org/1999.7792398x

Hahn, G. L. (1982). Housing for cattle, sheep and poultry in the Tropics. In M. Yousef (Ed.), Animal Production in the Tropics (pp. 43-72). Praeger Publishers, New York.

Hahn, G. L. (1985). Management and housing of farm animals in hot environments. In M. Yousef (Ed.), Stress physiology in livestock (Vol. 2, pp. 151-174). CRC Press, Boca Raton, FL.

Hahn, G. L. (1999). Dynamic responses of cattle to thermal heat load. Journal of Animal Science, 77(2), 10-20. http://dx.doi.org/1997.77suppl_210x

Hahn, G. L., \& Mader, T. L. (1997). Heat waves in relation to thermoregulation, feeding behavior, and mortality of feedlot cattle. Proceedings of the 5th International Livestock Environmental Symposium of the American Society of Agricultural Engineers (pp. 563-571). St. Joseph, MI.

Hammond, A. C., Chase Jr., C. C., Bowers, E. J., Olson, T. A., \& Randel, R. D. (1998). Heat tolerance in Tuli-, Senepol-, and Brahman sired $\mathrm{F}_{1}$ Angus heifers in Florida. Journal of Animal Science, 76, 1568-1577. http://dx.doi.org/1998.7661568x

Heady, H. F., Gibbens, R. P., \& Powell, R. W. (1959). A comparison of the charting, line intercept, and line point methods of sampling shrub types of vegetation. Journal of Range Management, 12, 180-188. http://dx.doi.org/10.2307/3894848

Higgins, S. F., Agouridis, C. T., \& Wightman, S. J. (2011). Shade options for grazing cattle. Coop. Ext. Service; Univ. of Kentucky, Lexington, KY. Retrieved December, 2014, from http://www2.ca.uky.edu/agc/pubs/aen /aen99/aen99.pdf

Kadzere, C. T., Murphy, M. R., Silanikove, N., \& Maltz, E. (2002). Heat stress in lactating dairy cows: A review. Livestock Production Science, 77, 59-91. http://dx.doi.org/10.1016/S0301-6226(01)00330-X

Mader, T. L., Dahlquist, J. M., Hahn, G. L., \& Gaughan, J. B. (1999). Shade and wind barrier effects on summer time feedlot cattle performance. Journal of Animal Science, 77, 2065-2072. http://dx.doi.org/1999.77 $82065 x$

Mader, T. L., Davis, M. S., \& Brown-Brandl, T. (2006). Environmental factors influencing heat stress in feedlot cattle. Journal of Animal Science, 84, 712-719. http://dx.doi.org/2006.843712x

Mishra, M., Martz, F. A., Stanley, R. W., Johnson, H. D., Campbell, J. R., \& Hilderbrand, E. (1970). Effect of diet and ambient temperature-humidity on ruminal $\mathrm{pH}$, oxidation reduction potential, ammonia and lactic acid in lactating cows. Journal of Animal Science, 30, 1023-1028. http://dx.doi.org/10.2134/jas1970. $3061023 x$

Mitloehner, F. M., Morrow, J. L., Daily, J. W., Wilson, S. C., Galyean, M. L., Miller, M. F., \& McGlone, J. J. (2001). Shade and water misting effects on behavior, physiology, performance, and carcass traits of heat-stressed feedlot cattle. Journal of Animal Science, 79, 2327-2335. http://dx.doi.org/2001.7992327x

National Weather Service. (2016). NWS Forecast Office. Retrieved from http://www.nws.noaa.gov/climate/ xmacis.php?wfo=lch

NRC. (1996). Nutrient Requirements of Beef Cattle (7th rev. ed.). Natl. Acad. Press, Washington, DC. 
Oates, L. G., Undersander, D. J., Gratton, C., Bell, M. M., \& Jackson, R. D. (2011). Management-intensive rotational grazing enhances forage production and quality of sub-humid cool-season pastures. Crop Science, 51, 892-901. http://dx.doi.org/ 10.2135/cropsci2010.04.0216

Paul, R. M., Turner, L. W., \& Larson, B. L. (1999). Effects of shade on tympanic temperatures and production parameters of grazing beef cows. American Society of Agricultural Engineers, Paper No. 99-4216.

Robinson, J. B., Ames, D. R., \& Milliken, G. A. (1986). Heat production of cattle acclimated to cold, thermoneutrality and heat when exposed to thermoneutrality and heat stress. Journal of Animal Science, 62, 1434-1440. http://dx.doi.org/10.2134/jas1986.6251434x

Rutter, S. M., Champion, R. A., \& Penning, P. D. (1997). An automatic system to record foraging behaviour in free-ranging ruminants. Applied Animal Behaviour Science, 54, 185-195. http://dx.doi.org/10.1016/S01681591(96)01191-4

Scaglia, G., \& Boland, H. T. (2014). The effect of bermudagrass hybrid on forage characteristics, animal performance, and grazing behavior of beef steers. Journal of Animal Science, 92, 1228-1238. http://dx.doi.org/10.2527/jas.2013-6959

Scientific Committee on Animal Health and Animal Welfare. (2001). The welfare of cattle kept for beef production. SANCO.C.2/AH/R22/2000. Retrieved March 27, 2014, from http://europa.eu.int/comm/food/fs/ sc/scah/outcome_en.html

Silanikove, N. (2000). Effects of heat stress on the welfare of extensively managed domestic ruminants. Livestock Production Science, 67, 1-18. http://dx.doi.org/10.1016/S0301-6226(00)00162-7

Sprinkle, J. E., Holloway, J. W., Warrington, B. G., Ellis, W. C., Stuth, J. W., Forbes, T. D., \& Greene, L. W. (2000). Digesta kinetics, energy intake, grazing behavior, and body temperature of grazing beef cattle differing in adaptation to heat. Journal of Animal Science, 78, 1608-1624. http://dx.doi.org/2000.7861608x

St. Pierre, N. R., Cobanov, B., \& Schnitkey, G. (2003). Economic losses from heat stress by US livestock industries. Journal of Dairy Science, 86, E52-E77. http://dx.doi.org/10.3168/jds.S0022-0302(03)74040-5

Teutsch, C. (2009). Warm-Season Annual Grasses for Summer Forage. Virginia Coop. Ext pub. $418-004$. Blacksburg, VA. Retrieved June 12, 2015, from https://pubs.ext.vt.edu/418/418-004/418-004_pdf.pdf

Valtorta, S. E., Leva, P. E., \& Gallardo, M. R. (1997). Evaluation of different shades to improve dairy cattle well-being in Argentina. International Journal of Biometeorology, 41, 65-67. http://dx.doi.org/10.1007/ s004840050055

Van Soest, P. J., Robertson, J. B., \& Lewis, B. A. (1991). Methods for dietary fiber, neutral detergent fiber, and non-starch polysaccharides in relation to animal nutrition. Journal of Dairy Science, 74, 3583-3597. http://dx.doi.org/10.3168/jds.S0022-0302(91)78551-2

West, J. W. (1994). Interactions of energy and bovine somatotropin with heat stress. Journal of Dairy Science, 77, 2091-2102. http://dx.doi.org/10.3168/jds.S0022-0302(94)77152-6

\section{Copyrights}

Copyright for this article is retained by the author(s), with first publication rights granted to the journal.

This is an open-access article distributed under the terms and conditions of the Creative Commons Attribution license (http://creativecommons.org/licenses/by/4.0/). 